\title{
Sexual morph of Lasiodiplodia pseudotheobromae (Botryosphaeriaceae, Botryosphaeriales, Dothideomycetes) from China
}

\author{
Tennakoon DS ${ }^{1,2,3,4}$, Phillips AJL ${ }^{5}$, Phookamsak $\mathbf{R}^{1,2,3,4}$, Ariyawansa $\mathrm{HA}^{1,2,3,4}$ \\ Bahkali $\mathrm{AH}^{6}$ and Hyde $\mathrm{KD}^{1,2,3,4}$
}

\author{
${ }^{1}$ World Agro Forestry Centre, East and Central Asia, 132 Lanhei Road, Kunming 650201, Yunnan China \\ ${ }^{2}$ Key Laboratory for Plant Biodiversity and Biogeography of East Asia (KLPB), Kunming Institute of Botany, Chinese \\ Academy of Science, Kunming 650201, Yunnan China \\ ${ }^{3}$ Center of Excellence in Fungal Research, Mae Fah Luang University, Chiang Rai, 57100, Thailand \\ ${ }^{4}$ School of Science, Mae Fah Luang University, Chiang Rai, 57100, Thailand \\ ${ }^{5}$ University of Lisbon, Faculty of Sciences, Biosystems and Integrative Sciences Institute (BioISI), Campo Grande, \\ 1749- 016 Lisbon, Portugal \\ ${ }^{6}$ Department of Botany and Microbiology, King Saud University, Riyadh, Saudi Arabia
}

Tennakoon DS, Phillips AJL, Phookamsak R, Ariyawansa HA, Bahkali AH, Hyde KD 2016 Sexual morph of Lasiodiplodia pseudotheobromae (Botryosphaeriaceae, Botryosphaeriales, Dothideomycetes) from China. Mycosphere 7(7), 990-1000, Doi 10.5943/mycosphere/si/1b/11

\begin{abstract}
The sexual morph recorded here for Lasiodiplodia pseudotheobromae, was collected from dead leaves of Plukenetia volubilis L. (Euphorbiaceae) in Yunnan Province, China. The sexualasexual connection in Lasiodiplodia pseudotheobromae was confirmed by phylogenetic analyses of combined ITS and tefl- $\alpha$ sequence data. This is the first report of a sexual morph with molecular evidence for this species. The important characteristics of this species are immersed to erumpent ascomata, papillate ostioles, cylindric-clavate asci with a short pedicel, well-developed ocular chamber and ellipsoidal to fusiform, golden to dark brown, aseptate ascospores. The sexual morph of this species is compared with other Lasiodiplodia sexual morphs and a comprehensive description and micrographs are provided.
\end{abstract}

Key words - Morphology - phylogeny - taxonomy

\section{Introduction}

Botryosphaeriaceae is a well-established and diverse family in the order Botryosphaeriales of Dothideomycetes. The family was introduced by Theissen \& Sydow (1918) as a sub-family of Pseudosphaeriaceae (Liu et al. 2012, Abdollahzadeh et al. 2013, Phillips et al. 2013, Netto et al. 2014, Coutinho et al. 2016). Taxa in Botryosphaeriaceae are morphologically diverse and can be characterized by uni- to multilocular ascomata with multi-layered walls, hyaline, hypha-like pseudoparaphyses, bitunicate asci and hyaline, pale or dark brown ascospores (Liu et al. 2012, Phillips et al. 2013). Species of Botryosphaeriaceae are cosmopolitan in distribution occurring on a wide range of hosts from tropical and temperate regions, as pathogens, endophytes or saprobes (von Arx \& Müller 1954, Barr 1987, Abdollahzadeh et al. 2013, Phillips et al. 2013, Slippers et al. 2013, Machado et al. 2014). Many sexual and asexual genera have been introduced in Botryosphaeriaceae (Phillips et al. 2005, Crous et al. 2006, Phillips et al. 2008, Schoch et al. 2009, Liu et al. 2012, Wijayawardene et al. 2012, Hyde et al. 2013, 2014). 
Lasiodiplodia was introduced by Ellis and Everhart (1894) with L. tubericola as the type species, although the genus was formally described by Clendenin (1896). Species of Lasiodiplodia commonly occur in tropical and subtropical regions and some cause severe damage especially to cultivated plants (Punithalingam 1980, Netto et al. 2014, Correia et al. 2016, Rosado et al. 2016). Lasiodiplodia species can be distinguished from morphologically closely related genera in having pycnidial paraphyses and longitudinal striations on the mature conidia (Sutton 1980, Phillips et al. 2008, Abdollahzadeh et al. 2010, Netto et al. 2014). According to Index Fungorum (2016) there are 42 Lasiodiplodia species. However, the sexual morphs of Lasiodiplodia species have rarely been recorded and are known for only three Lasiodiplodia species, namely, L. gonubiensis Pavlic, Slippers \& M.J. Wingf., L. lignicola (Ariyaw., J.K. Liu \& K.D Hyde) A.J.L. Phillips, A. Alves \& Abdollahz and L. theobromae (Pat.) Griffon \& Maubl. (Liu et al. 2012, Phillips et al. 2013, Trakunyingcharoen et al. 2015).

The aim of the present paper is to report for the first time the sexual morph of Lasiodiplodia pseudotheobromae, which was collected from dead leaves of Plukenetia volubilis in Xishuangbanna (Yunnan Province), China. The identity of our strain (MFLUCC 16-0805) as Lasiodiplodia pseudotheobromae was confirmed by phylogenetic analyses of combined ITS and tefl- $\alpha$ sequence data by maximum-likelihood (ML), maximum-parsimony (MP) and Bayesian Inference (BI).

\section{Materials \& Methods}

\section{Sample collection, morphological studies and isolation}

Fresh specimens were collected from Xishuangbanna in Yunnan Province, China. Specimens were taken to the laboratory in zip lock bags and examined with a JNOEC series JSZ4 stereomicroscope. Micro-morphological characters were determined with an Olympus series SZ61 compound microscope. Hand cut sections of ascomata were mounted in sterile water for microscopic studies and photomicrography. Images were taken with a Nikon Eclipse 80i compound microscope with a Canon EOS 600D digital camera. Permanent slides were prepared by mounting fungal material in lactoglycerol and sealed by applying nail-polish around the margins of cover slips. Measurements were made with the Tarosoft (R) Image Frame Work program and images used for figures were processed with Adobe Photoshop CS3 extended version 10.0 (Adobe Systems, USA).

Isolates were obtained from single ascospores following the methods described in Chomnunti et al. (2014). Germinated ascospores were transferred to potato dextrose agar (PDA) and incubated at $25^{\circ} \mathrm{C}$ in normal light. Culture characteristics were observed after two weeks. Specimens were deposited in the Mae Fah Luang University Herbarium (MFLU), Chiang Rai, Thailand and Kunming Institute of Botany herbarium (HKAS). Living cultures were deposited in Mae Fah Luang University Culture Collection (MFLUCC) and Kunming Institute of Botany Culture Collection (KUMCC). Faces of Fungi numbers are registered as described in Jayasiri et al. (2015).

\section{DNA extraction and PCR amplification}

Genomic DNA was extracted from mycelium with Biospin fungus Genomic DNA extraction kit (BioFlux ${ }^{\circledR}$, Hangzhou, P. R. China) following the manufacturer's protocol. DNA was kept at $4^{\circ} \mathrm{C}$ for the DNA amplification and maintained at $-20^{\circ} \mathrm{C}$ for long term storage. The ITS region was amplified with primers ITS1 and ITS4 (White et al. 1990) as described in Alves et al. (2004). The primers TEF1-728F and TEF1-986R (Carbone and Kohn, 1999) were used to amplify translation elongation factor (tefl- $\alpha$ ) as described in Phillips et al. (2005). Quality of PCR products were checked on $1 \%$ agarose electrophoresis gels stained with ethidium bromide. The amplified PCR fragments were sequenced by Sangon Biotech (Shanghai) Co., Ltd, P.R. China. Nucleotide sequences were deposited in GenBank (Table 1). 
Sequencing and sequence alignment

Sequence homologies for the assembled consensus sequences were analyzed by BLAST searches of the National Center for Biotechnology Information (NCBI) and for the preliminary identification of the isolates used in the analyses. Other sequences used in the analyses (Table 1) were obtained from GenBank based on recently published data (Abdollahzadeh et al. 2013, Coutinho et al. 2016).

\section{Phylogenetic analysis}

The multiple alignments were made with MAFFT v. 7 at the web server (http://mafft.cbrc.jp/alignment/server), using default settings (Katoh \& Standley 2013). The alignment was refined manually with BioEdit v. 7.0.5.2 (Hall 1999) where necessary. Maximum likelihood analysis was performed by RAxML (Stamatakis 2010) implemented in RAxMLGUI 1.3 (Silvestro \& Michalak 2012). Maximum parsimony analysis (MP) was performed in PAUP v. $4.0 \mathrm{~b} 10$ (Swofford 2002), with the heuristic search option and 1,000 random replicates. Maxtrees was set to 1000 and branches of zero length were collapsed and all multiple parsimonious trees were saved. Descriptive tree statistics for parsimony (Tree Length [TL], Consistency Index [CI], Retention Index [RI], Relative Consistency Index [RC] and Homoplasy Index [HI] were calculated for trees generated under different optimality criteria. The Kishino-Hasegawa tests (Kishino \& Hasegawa 1989) were performed to determine whether the trees inferred under different optimality criteria were meaningfully different.

Evolutionary models for phylogenetic analyses were selected independently for each locus using MrModeltest v. 3.7 (Posada \& Crandall 1998) under the Akaike Information Criterion (AIC). A Bayesian analysis was conducted with MrBayes v. 3.1.2 (Huelsenbeck \& Ronqvist 2001) to evaluate posterior probabilities (PP) (Rannala \& Yang 1996, Zhaxybayeva \& Gogarten 2002) by Markov Chain Monte Carlo sampling (BMCMC). Phylograms were visualized with FigTree v1.4.0 program (Rambaut, 2012) and annotated in Microsoft Power Point (2010). The final alignment and tree were deposited in TreeBASE, submission ID: 20127.

Table 1 GenBank and culture collection accession numbers of species included in the phylogenetic study. The newly generated sequence is shown in blue. The ex-type strains are shown as bold.

\begin{tabular}{llll}
\hline \multirow{2}{*}{ Taxon } & Culture accession no.* & \multicolumn{2}{c}{ GenBank Accession no. } \\
\cline { 3 - 4 } & ITS & tef1- $\boldsymbol{\alpha}$ \\
\hline Diplodia corticola & CBS 112547 & AY259110 & DQ458872 \\
Diplodia corticola & CBS 112549 & KF766156 & KF766398 \\
Diplodia cupressi & CBS 168.87 & KF766157 & DQ458878 \\
Diplodia cupressi & CBS 261.85 & DQ458894 & DQ458879 \\
Diplodia mutila & CBS 112553 & AY259093 & AY573219 \\
Diplodia mutila & CBS 230.30 & DQ458886 & DQ458869 \\
Diplodia pinea & CBS 109725 & DQ458896 & DQ458881 \\
Diplodia pinea & CBS 109943 & DQ458898 & DQ458883 \\
Diplodia scrobiculata & CBS 109944 & DQ458899 & DQ458884 \\
Diplodia scrobiculata & CBS 113423 & DQ458900 & DQ458885 \\
Diplodia seriata & CBS 112555 & AY25909 & AY573220 \\
Diplodia seriata & CBS 119049 & DQ458889 & DQ458874 \\
Diplodia tsugae & CBS 418.64 & DQ458888 & DQ458873 \\
Lasiodiplodia citricola & IRAN 1521 & GU945353 & GU945339 \\
Lasiodiplodia citricola & IRAN 1522 & GU945354 & GU945340 \\
Lasiodiplodia crassispora & CMW 13488 & DQ103552 & DQ103559
\end{tabular}




\begin{tabular}{|c|c|c|c|}
\hline \multirow{2}{*}{ Taxon } & \multirow{2}{*}{ Culture accession no.* } & \multicolumn{2}{|c|}{ GenBank Accession no. } \\
\hline & & ITS & tefl- $\alpha$ \\
\hline Lasiodiplodia crassispora & WAC 12533 & DQ103550 & DQ103557 \\
\hline Lasiodiplodia gilanensis & IRAN 1501 & GU945352 & GU945341 \\
\hline Lasiodiplodia gilanensis & IRAN 1523 & GU945351 & GU945342 \\
\hline Lasiodiplodia gonubiensis & CBS 116355 & AY639594 & DQ103567 \\
\hline Lasiodiplodia gonubiensis & CBS 115812 & DQ458892 & DQ458877 \\
\hline Lasiodiplodia hormozganensis & IRAN 1498 & GU945356 & GU945344 \\
\hline Lasiodiplodia hormozganensis & IRAN 1500 & GU945355 & GU945343 \\
\hline Lasiodiplodia iraniensis & IRAN921 & GU945346 & GU945334 \\
\hline Lasiodiplodia iraniensis & IRAN 1502 & GU945347 & GU945335 \\
\hline Lasiodiplodia lignicola & MFLUCC 11-0435 & JX646797 & JX646862 \\
\hline Neofusicoccum luteum & CBS 110299 & AY259091 & AY573217 \\
\hline Lasiodiplodia parva & CBS494.78 & EF622084 & EF622064 \\
\hline Lasiodiplodia parva & CBS 495.78 & EF622085 & EF622065 \\
\hline Lasiodiplodia pseudotheobromae & CBS 304.79 & EF622079 & EF622061 \\
\hline Lasiodiplodia pseudotheobromae & CBS 374.54 & EF622080 & EF622059 \\
\hline Lasiodiplodia pseudotheobromae & CBS 116460 & EF622078 & EF622058 \\
\hline Lasiodiplodia pseudotheobromae & CBS 116459 & EF622077 & EF622057 \\
\hline Lasiodiplodia pseudotheobromae & IBL 241 & KT247479 & KT247483 \\
\hline Lasiodiplodia pseudotheobromae & CJA 36 & GU973875 & GU973867 \\
\hline Lasiodiplodia pseudotheobromae & MFLUCC 16-0805 & KY056126 & KY056125 \\
\hline Lasiodiplodia pseudotheobromae & IBL 266 & KT247480 & KT247484 \\
\hline Lasiodiplodia rubropurpurea & WAC 12535 & DQ103553 & DQ103571 \\
\hline Lasiodiplodia rubropurpurea & WAC 12536 & DQ103554 & DQ103572 \\
\hline Lasiodiplodia theobromae & CAA 006 & DQ458891 & DQ458876 \\
\hline Lasiodiplodia theobromae & CBS 112874 & EF622075 & EF622055 \\
\hline Lasiodiplodia theobromae & CBS 113520 & EF622074 & EF622054 \\
\hline Lasiodiplodia theobromae & CBS 289.56 & EF622070 & EF622050 \\
\hline Lasiodiplodia venezuelensis & WAC 12539 & DQ103547 & DQ103568 \\
\hline Lasiodiplodia venezuelensis & WAC 12540 & DQ103548 & DQ103569 \\
\hline
\end{tabular}

Abbreviations of culture collections: CAA A. Alves, Universidade de Aveiro, Portugal; CBS Centraalbureau voor Schimmelcultures, Utrecht, Netherlands; CJA Kurdistan University, Sanandaj, Kurdistan Province, Iran; CMW Tree Pathology Co-operative Program, Forestry and Agricultural Biotechnology Institute, University of Pretoria, South Africa; IBL Independent Biological Laboratories, Israel; IRAN Iranian Research Institute of Plant Protection, Iran, Tehran; MFLUCC Mae Fah Luang University Culture Collection, Chiang Rai, Thailand; WAC Department of Agriculture Western Australia Plant Pathogen Collection, Perth, Australia.

\section{Results}

Phylogenetic analysis

The combined ITS and tefl- $\alpha$ dataset consisted of 45 taxa including our strain (Lasiodiplodia pseudotheobromae; MFLUCC16-0805), with Neofusicoccum luteum (CBS 110299) as the outgroup taxon. The combined dataset consisted of 847 constant characters and 44 parsimony-uninformative characters. Maximum parsimony analysis of the remaining 165 parsimony-informative characters resulted in 1000 trees with $\mathrm{TL}=405, \mathrm{CI}=0.704, \mathrm{RI}=0.896, \mathrm{RC}$ $=0.630, \mathrm{HI}=0.296$. Maximum likelihood $(\mathrm{ML})$, maximum parsimony $(\mathrm{MP})$ and Bayesian 




Fig. 1 RAxML tree based on analysis of a combined ITS and tefl- $\alpha$ partial sequences. Bootstrap support values for maximum parsimony (MP, red) and maximum likelihood (ML, black) greater than $70 \%$ are defined above the nodes. Bayesian posterior probabilities (PP) greater than 0.90 are shown as bold branches. The tree is rooted to Neofusicoccum luteum (CBS 110299). The new strain is shown in blue. Ex-type strains are shown in bold.

posterior probability analyses (PP) resulted in trees with similar topologies that did not differ significantly from one another (data not shown). The final RAxML tree is shown in Fig. 1, with the final ML optimization likelihood value of -3295.519404 (ln). The sexual morph of Lasiodiplodia pseudotheobromae strain (MFLUCC 16-0805) clustered with other strains of Lasiodiplodia pseudotheobromae in a well-supported clade (91\% ML, 83\% MP, 0.91 PP, Fig. 1). 
Taxonomy below.

An emended description of Lasiodiplodia pseudotheobromae is provided and discussed

Lasiodiplodia pseudotheobromae A.J.L. Phillips, A. Alves \& Crous, Fungal Diversity 28: 8 (2007).

Fig. 2

Facesoffungi number: FoF0264

Saprobic on dead leaves of Plukenetia volubilis L. Sexual morph: Ascomata apearing as black spots on host surface, globose to subglobose, 270-320 $\mu \mathrm{m}$ diam., 265-275 $\mu \mathrm{m}$ high, gregarious, scattered to clustered, immersed or erumpent through host surface, slightly raised, glabrous, uni-loculate. Ostioles up to 59-63 $\mu \mathrm{m}$ diam., 68-73 $\mu \mathrm{m}$ high, setae- like periphyses, central circular, papillate. Peridium 35-45 $\mu \mathrm{m}$ wide, thin to thick-walled with equal thickness, composed of several layers of dark brown to black pseudoparenchymatous cells, arranged in a textura angularis to textura prismatica. Hamathecium composed of dense, broad cellular pseudoparaphyses, 3.2-3.9 $\mu \mathrm{m}$ wide, filamentous, septate, constricted at the septum, anastomosing at the apex, embedded in a hyaline gelatinous matrix. Asci (159-)168-182(-219) $\times(24-) 28-31(-$ 40) $\mu \mathrm{m}(\bar{x}=178 \times 29.9 \mu \mathrm{m}, \mathrm{n}=20), 8$-spored, bitunicate, fissitunicate, cylindric-clavate, short furcate or obtuse pedicel, apically rounded, with well-developed ocular chamber. Ascospores $(31.5-) 35-38(-41) \times 14-16 \mu \mathrm{m}(\bar{x}=36.1 \times 15.5 \mu \mathrm{m}, \mathrm{n}=20)$, overlapping uni- to bi-seriate, ellipsoidal to fusiform, with rounded ends, initially hyaline to pale yellowish, becoming golden to dark brown at maturity, aseptate, straight to curved, smooth-walled. Asexual morph: see Alves et al. (2008).

Culture characteristics: Colonies on PDA reaching $37 \mathrm{~mm}$ diameter after 2 weeks at 20-25 ${ }^{\circ} \mathrm{C}$, colonies medium sparse, circular, flat, surface slightly rough with edge entire, margin welldefined, cottony to fairly fluffy with sparse aspects, colony from above: brown to black at the margin, white to grey at the centre; reverse, brown to black at the margin, light brown to yellowish at the centre; mycelium light brown to whitish grey with tufting; not producing pigments in PDA.

Material examined: China, Yunnan Province, Xishuangbanna, Nabanhe, dead leaves of Plukenetia volubilis L. (Euphorbiaceae), 20 November 2015, D.S. Tennakoon, DXH 024 (MFLU 16-1386, ibid. HKAS 93716), living culture, MFLUCC 16-0805, KUMCC 15-0571.

Notes: The sexual morphs of Lasiodiplodia species have rarely been recorded and are known only for L. gonubiensis, L. lignicola and L. theobromae. Morphologically, Lasiodiplodia pseudotheobromae is distinct from the sexual morphs of these other species. Lasiodiplodia pseudotheobromae resembles L. gonubiensis in having dark brown to black, unilocular, globose ascomata with central ostiole but, Lasiodiplodia gonubiensis has ascospores with a terminal apiculus, which is not found in L. pseudotheobromae. Ascospores of L. gonubiensis are normally hyaline, becoming pigmented and septate when the ascospores are released, but in $L$. pseudotheobromae ascospores are golden to dark brown and aseptate. Lasiodiplodia lignicola differs morphologically from L. pseudotheobromae in having multi-loculate ascomata, size range of ascomata, asci and host occurrence (Table 2.), although, the size range and colour of ascospores is quite similar to L. pseudotheobromae. The size ranges of Lasiodiplodia species sexual morphs are shown in Table 2.

\section{Key to recorded sexual morphs of Lasiodiplodia species}

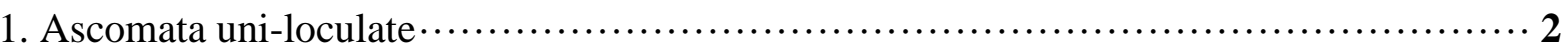

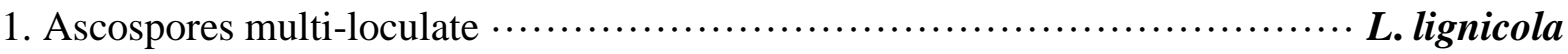

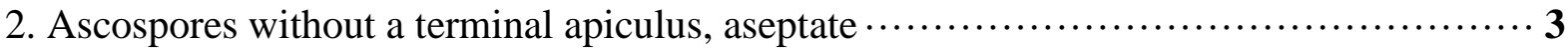

2. Ascospores with a terminal apiculus, 1-2-septate within ascoma or shortly after discharge

3. Ascospores hyaline, associated with various hosts $\ldots \ldots \ldots \ldots \ldots \ldots \ldots \ldots \ldots \ldots \ldots \ldots \ldots$. theobromae

3. Ascospores golden brown, associated with Plukenetia volubilis L L. pseudotheobromae 




Fig. 2 - Lasiodiplodia pseudotheobromae (MFLUCC 16-0805) a Appearance of ascomata on the host. b Vertical section of ascoma. c Section of peridium. d Section through neck. e Asci embedded in pseudoparaphyses. f Immature ascus. $\mathbf{g}-\mathbf{i}$ Asci. $\mathbf{j}-\mathbf{m}$ Ascospores. $\mathbf{n}$ Germinated ascospore. o Colony from above. $\mathbf{p}$ Colony from below. Scale bars: $\mathrm{b}=50 \mu \mathrm{m}, \mathrm{c}-\mathrm{e}=20 \mu \mathrm{m}, \mathrm{f}-\mathrm{i}=50 \mu \mathrm{m}, \mathrm{j}-\mathrm{m}=$ $5 \mu \mathrm{m}, \mathrm{n}=50 \mu \mathrm{m}$.

\section{Discussion}

In this study, we describe the sexual morph of a strain of Lasiodiplodia pseudotheobromae that was identified based on analysis of combined ITS and TEF- $\alpha$ genes. This is the first time a sexual morph has been reported for this species.

The sexual morphs of Lasiodiplodia are known only in Lasiodiplodia theobromae, L. lignicola and L. gonubiensis. Lasiodiplodia pseudotheobromae can be distinguished from $L$. theobromae in having golden brown to dark brown ascospores and setae-like periphyses in the ostiole. In L. theobromae, ascospores are hyaline and periphyses are lacking. The size range of asci and hosts also differ in $L$. theobromae. However, the sexual-asexual morph connection of $L$. theobromae has not yet been conclusively proven (Phillips et al. 2013). Liu et al. (2012) introduced Auerswaldia lignicola as a new sexual morph species. Phillips et al. (2013) transferred this species to Lasiodiplodia as L. lignicola. Lasiodiplodia lignicola was characterized by multi-loculate ascomata and ascospores that are reddish-brown to dark brown, aseptate, fusiform to ellipsoid and with narrowly rounded ends. The sexual morph of Lasiodiplodia gonubiensis was described by Trakunyingcharoen et al. (2015) and is characterized by having hyaline, aseptate ascospores, that rarely turn pale brown, that are 1-2 septate within the ascoma or shortly after discharge and have hyaline apiculi at both or either ends. 
As a result of this study the number of species of Lasiodiplodia with known sexual morphs increases to four. Our observations confirm that ascospores of Lasiodiplodia species are coloured and can be 1- or 2-septate. Further collections are required to resolve the sexual and asexual linkage of other Lasiodiplodia species.

Table 2 Synopsis of recorded sexual morphs of Lasiodiplodia species discussed in this study

\begin{tabular}{|c|c|c|c|c|c|c|}
\hline \multirow{2}{*}{$\begin{array}{l}\text { Lasiodiplodia } \\
\text { species }\end{array}$} & \multicolumn{3}{|c|}{ Size $(\mu \mathrm{m})$} & \multicolumn{2}{|c|}{ Ascospores } & \multirow{2}{*}{ References } \\
\hline & Ascomata & Asci & Ascospores & septation & Colour & \\
\hline L. gonubiensis & $\begin{array}{l}530-600 \times \\
400-500\end{array}$ & $\begin{array}{l}150-180 \times \\
27.5-30\end{array}$ & $\begin{array}{l}35-37.5 \times \\
17.5-20\end{array}$ & $\begin{array}{l}\text { Rarely } 1- \\
2 \text { septate }\end{array}$ & $\begin{array}{l}\text { Rarely pale } \\
\text { brown }\end{array}$ & $\begin{array}{l}\text { Trakunyingcharoen } \\
\text { et al. } 2015\end{array}$ \\
\hline L. lignicola & $\begin{array}{l}500-750 \times \\
500-1000\end{array}$ & $85 \times 15-20$ & $\begin{array}{l}15-20 \times 8- \\
10\end{array}$ & Aseptate & $\begin{array}{l}\text { Reddish } \\
\text { brown to dark } \\
\text { brown }\end{array}$ & Phillips et al. 2013 \\
\hline $\begin{array}{l}L . \\
\text { pseudotheobromae }\end{array}$ & $\begin{array}{l}270-320 \times \\
265-275\end{array}$ & $\begin{array}{l}168-182 \times \\
28-31\end{array}$ & $\begin{array}{l}35-38 \times \\
14-16\end{array}$ & Aseptate & $\begin{array}{l}\text { Golden to } \\
\text { dark brown }\end{array}$ & This study \\
\hline L. theobromae & $250-400$ & $90-120$ & $\begin{array}{l}30-35 \times \\
11-14\end{array}$ & Aseptate & Hyaline & Phillips et al. 2013 \\
\hline
\end{tabular}

\section{Acknowledgments}

We are grateful to Mae Fah Luang University and Kunming Institute of Botany for laboratory and financial support and deposit cultures and herbarium. K.D Hyde thanks the Chinese Academy of Sciences, (project number 2013T2S003), for the award of visiting Professorship for Senior International Scientists at Kunming Institute of Botany. MFLU grant number 56101020032 is thanked for supporting studies on Dothideomycetes. R. Phookamsak thanks the Royal Golden Jubilee Ph.D Program (PHD/0090/2551) under the Thailand Research Fund for financial support. Danushka Tennakoon is grateful to Dhanushka Wanasinghe, Milan Samarakoon and Nimali de Silva for their valuable suggestions.

\section{References}

Abdollahzadeh J, Javadi A, Goltapeh EM, Zare R, Phillips AJL. 2010 - Phylogeny and morphology of four new species of Lasiodiplodia from Iran. Persoonia 25, 1-10.

Abdollahzadeh J, Zare R, Phillips AJ. 2013 - Phylogeny and taxonomy of Botryosphaeria and Neofusicoccum species in Iran, with description of Botryosphaeria scharifii sp. nov. Mycologia 105, 210-220.

Alves A, Correia A, Luque J, Phillips AJL. 2004 - Botryosphaeria corticola sp. nov. on Quercus species, with notes and description of Botryosphaeria stevensii and its anamorph, Diplodia mutila. Mycologia 96, 598-613.

Alves A, Crous PW, Correia A, Phillips AJL. 2008 - Morphological and molecular data reveal cryptic speciation in Lasiodiplodia theobromae. Fungal Diversity 28, 1-13.

Barr ME. 1987 - Prodromus to class Loculoascomycetes. Published by the author. Amherst, Massachusetts.

Carbone I, Kohn LM. 1999 - A method for designing primer sets for speciation studies in filamentous ascomycetes. Mycologia 91, 553-556.

Chomnunti P, Hongsanan S, Hudson BA, Tian Q, Persoh D, Dhami MK, Alias AS, Xu J, Liu X, Stadler M, Hyde KD. 2014 - The Sooty Moulds. Fungal Diversity 66, 1-36.

Clendenin I. 1896 - Lasiodiplodia E. \& E., n. gen. Botanical Gazette 21, 92-93.

Correia KC, Silva MA, Morais MA, Armengol J, Phillips AJL, Câmara MPS, Michereff SJ. 2016 Phylogeny, distribution and pathogenicity of Lasiodiplodia species associated with dieback of table grape in the main Brazilian exporting region. Plant Pathology 65, 92-103. 
Coutinho IBL, Freire FCO, Lima CS, Lima JS, Gonçalves FJT, Machado AR, Silva A, Cardoso JE. 2016 - Diversity of genus Lasiodiplodia associated with perennial tropical fruit plants in northeastern Brazil. Plant Pathology, Doi: 10.1111/ppa.12565.

Crous PW, Slippers B, Wingfield MJ, Rheeder J, Marasas WFO, Phillips AJL, Alves A, Burgess T, Barber P, Groenewald JZ. 2006 - Phylogenetic lineages in the Botryosphaeriaceae. Studies in Mycology 55, 235-253.

Ellis JB, Everhart BM. 1894 - New species of fungi from various localities. Proceedings of the Academy of Natural Sciences of Philadelphia. 46, 322-386.

Hall TA. 1999 - BioEdit: a user- friendly biological sequence alignment editor and analysis program for Windows 95/98/NT. Nucleic Acids Symposium Series 41, 95-98.

Huelsenbeck JP, Ronqvist F. 2001 - MRBAYES: Bayesian inference of phylogenetic trees. Bioinformatics 17, 754-755.

Hyde KD, Jones EBG, Liu JK, Ariyawansa H, Boehm E, Boonmee S, Braun U, Chomnunti P, Crous PW, Dai DQ, Diederich P, Dissanayake A, Doilom M, Doveri F, Hongsanan S, Jayawardena R, Lawrey JD, Li YM, Liu YX, Lücking R, Monkai J, Muggia L, Nelsen MP, Pang KL, Phookamsak R, Senanayake IC, Shearer CA, Suetrong S, Tanaka K, Thambugala KM, Wijayawardene NN, Wikee S, Wu HX, Zhang Y, Aguirre-Hudson B, Alias SA, Aptroot A, Bahkali AH, Bezerra JL, Bhat DJ, Camporesi E, Chukeatirote E, Gueidan C, Hawksworth DL, Hirayama K, Hoog SD, Kang JC, Knudsen K, Li WJ, Li XH, Liu ZY, Mapook A, McKenzie EHC, Miller AN, Mortimer PE, Phillips AJL, Raja HA, Scheuer C, Schumm F, Taylor JE, Tian Q, Tibpromma S, Wanasinghe DN, Wang Y, Xu JC, Yacharoen S, Yan JY, Zhang M. 2013 - Families of Dothideomycetes. Fungal Diversity 63, 1-313.

Hyde KD, Nilsson RH, Alias SA, Ariyawansa H, Blair JE, Cai L, de Cock AWAM, Dissanayake AJ, Glockling SJ, Goonasekara ID, Gorczak M, Hahn M, Jayawardena RS, van Kan JAL, Laurence MH, Lévesque CA, Li XH, Liu JK, Maharachchikumbura SSN, Manamgoda DS, Martin FN, McKenzie EHC, McTaggart AR, Mortimer PE, Nair PVR, Pawłowska J, Rintoul TL, Shivas RG, Spies CFJ, Summerell BA, Taylor PWJ, Terhem RB, Udayanga D, Vaghefi N, Walther G, Wilk M, Wrzosek M, Xu JC, Yan JY, Zhou N. 2014 - One stop shop: backbones trees for important phytopathogenic genera: I. Fungal Diversity 67, 21125.

Index Fungorum 2016 - http://www.indexfungorum.org/Names/Names.asp. Accessed on October 2016.

Jayasiri CS, Hyde KD, Ariyawansa HA, Bhat J, Buyck B, Cai L, Dai YC, Abd-Elsalam KA, Ertz D, Hidayat I, Jeewon R, Jones EBG, Bahkali AH, Karunarathna SC, Liu JK, Luangsa-ard JJ, Lumbsch HT, Maharachchikumbura SSN, McKenzie EHC, Moncalvo JM, GhobadNejhad M, Nilsson H, Pang KL, Pereira OL, Phillips AJL, Raspé O, Rollins AW, Romero AI, Etayo J, Selçuk F, Stephenson SL, Suetrong S, Taylor JE, Tsui CKM, Vizzini A, AbdelWahab MA, Wen TC, Boonmee S, Dai DQ, Daranagama DA, Dissanayake AJ, Ekanayaka AH, Fryar SC, Hongsanan S, Jayawardena RS, Li WJ, Perera RH, Phookamsak R, De Silva NI, Thambugala KM, Tian Q, Wijayawardene NN, Zhao RL, Zhao Q, Kang JC, Promputtha I. 2015 - The Faces of Fungi database: fungal names linked with morphology, phylogeny and human impacts. Fungal Diversity 74, 3-18.

Katoh K, Standley K. 2013 - MAFFT Multiple Sequence Alignment Software Version 7: Improvements in Performance and Usability. Molecular Biology \& Evolution 30, 772-780.

Kishino H, Hasegawa M. 1989 - Evaluation of the maximum likelihood estimate of the evolutionary tree topologies from DNA - sequence data, and the branching order in Hominoidea. Journal of Molecular Evolution 29, 170-179.

Liu JK, Phookamsak R, Doilom M, Wikee S, Li YM, Ariyawansa HA, Boonmee S, Chomnunti P, Dai DQ, Bhat JD, Romero AI. 2012 - Towards a natural classification of Botryosphaeriales. Fungal Diversity 57, 149-210. 
Machado AR, Pinho DB, Pereira OL. 2014 - Phylogeny, identification and pathogenicity of the Botryosphaeriaceae associated with collar and root rot of the biofuel plant Jatropha curcas in Brazil, with a description of new species of Lasiodiplodia. Fungal Diversity 67, 231-247.

Netto MS, Assunção IP, Lima GS, Marques MW, Lima WG, Monteiro JH, de Queiroz Balbino V, Michereff SJ, Phillips AJ, Câmara MP. 2014 - Species of Lasiodiplodia associated with papaya stem-end rot in Brazil. Fungal Diversity 67, 127-141.

Phillips AJL, Alves A, Correia A, Luque J. 2005 - Two new species of Botryosphaeria with brown, 1-septate ascospores and Dothiorella anamorphs. Mycologia 97, 513-529.

Phillips AJL, Alves A, Pennycook SR, Johnston PR, Ramaley A. 2008 - Resolving the phylogenetic and taxonomic status of dark-spored teleomorph genera in the Botryosphaeriaceae. Persoonia 21, 29-55.

Phillips AJL, Alves A, Abdollahzadeh J, Slippers B, Wingfield MJ, Groenewald JZ, Crous PW. 2013 - The Botryosphaeriaceae: genera and species known from culture. Studies in Mycology 76, 51-167.

Posada D, Crandall KA. 1998 - Modeltest: testing the model of DNA substitution. Bioinformatics $14,817-818$.

Punithalingam E. 1980 - Plant diseases attributed to Botryodiplodia theobromae Pat. Cramer, Vaduz.

Rambaut A. 2012 - FigTree version 1.4.0 Available at http://tree.bio.ed.ac.uk/software/figtree. Accessed October 2016.

Rannala B, Yang Z. 1996 - Probability distribution of molecular evolutionary trees: a new method of phylogenetic inference. Journal of Molecular Evolution 43, 304-311.

Rosado AWC, Machado AR, Freire FDCO, Pereira OL. 2016 - Phylogeny, identification, and pathogenicity of Lasiodiplodia associated with postharvest stem-end rot of coconut in Brazil. Plant Disease 100, 561-568.

Schoch CL, Crous PW, Groenewald JZ, Boehm EWA, Burgess TI, de Gruyter J, de Hoog GS, Dixon LJ, Grube M, Gueidan C, Harada Y, Hatakeyama S, Hirayama K, Hosoya T, Huhndorf SM, Hyde KD, Jones EB, Kohlmeyer J, Kruys A, Li YM, Lucking R, Lumbsch HT, Marvanova L, Mbatchou JS, McVay AH, Miller AN, Mugambi GK, Muggia L, Nelsen MP, Nelson P, Owensby CA, Phillips AJ, Phongpaichit S, Pointing SB, Pujade-Renaud V, Raja HA, Plata ER, Robbertse B, Ruibal C, Sakayaroj J, Sano T, Selbmann L, Shearer CA, Shirouzu T, Slippers B, Suetrong S, Tanaka K, Volkmann-Kohlmeyer B, Wingfield MJ, Wood AR, Woudenberg JH, Yonezawa H, Zhang Y, Spatafora JW. 2009 - A class-wide phylogenetic assessment of Dothideomycetes. Studies in Mycology 64, 1-15.

Silvestro D, Michalak I. 2012 - raxmlGUI: a graphical front-end for RAxML. Organisms Diversity \& Evolution 12, 335-337.

Slippers B, Boissin E, Phillips AJL, Groenewald JZ, Lombard L, Wingfield MJ, Postma A, Burgess T, Crous PW 2013 - Phylogenetic lineages in the Botryosphaeriales: a systematic and evolutionary framework. Studies in Mycology 76, 31-49.

Stamatakis A, Alachiotis N. 2010 - Time and memory efficient likelihood-based tree searches on phylogenomic alignments with missing data. Bioinformatics 26, i132-i139.

Sutton BC. 1980 - The Coelomycetes: Fungi imperfecti with pycnidia, acervuli and stromata. Commonwealth Mycological Institute, Kew, UK, 496pp.

Swofford DL, 2002 - PAUP: phylogenetic analysis using parsimony, version 4.0 b10. Sinauer Associates, Sunderland.

Theissen F, Sydow H. 1918 - Vorentwürfe zu den Pseudosphaeriales. Annales Mycologici 16, 134.

Trakunyingcharoen T, Lombard L, Groenewald JZ, Cheewangkoon R, To-Anun C, Crous PW. 2015 - Caulicolous Botryosphaeriales from Thailand. Persoonia 34, 87-99.

Von Arx J, Müller E. 1954 - Die Gattungen der amerosporen Pyrenomyceten. Beitrage zur Kryptogamenflora der Schweiz 11, 1-434. 
White T, Bruns T, Lee S, Taylor J. 1990 - Amplification and direct sequencing of fungal ribosomal RNA genes for phylogenetics. PCR Protocols: A Guide to Methods and Applications 18, 315-322.

Wijayawardene DNN, Mckenzie EHC, Hyde KD. 2012 - Towards incorporating anamorphic fungi in a natural classification - checklist and notes for 2011. Mycosphere 3, 157-228.

Zhaxybayeva O, Gogarten JP. 2002 - Bootstrap, Bayesian probability and maximum likelihood mapping: exploring new tools for comparative genome analyses. BMC genomics 3, 4 . 